\title{
Valuation Challenges in High Tech Platform Based Corporations*
}

Submitted 17/10/21, 1 st revision 10/11/21, 2nd revision 20/12/21, accepted 05/02/22

\begin{abstract}
Demetri Tsanacas ${ }^{1}$
Abstract:

Purpose: This paper explores the practical issues of information asymmetry as it pertains to the methods of valuation of high-tech platform-based corporations. The paper touches upon the theoretical discussion of the issues of asymmetry and valuation techniques and summarizes some of the published literary work on these issues, without engaging in an indepth discussion.

Design/Methodology/Approach: The methodology consists of an analysis and comparison/ contrast between supply, demand platform companies ((SDPs) with industry incumbents on: capital structure, weighted average cost of capital (WACC), working capital and liquidity management, and enterprise risk structure and management strategy as they pertain to discounted cash flows and multiples valuation techniques. Tables showcasing various types of financial data such as: assets and liabilities, equity, market capitalization, debt to equity and current ratios are utilized in making the comparisons and drawings conclusions

Findings: The research shows that the peculiar and complicated structure, the ability to raise funds, the initial high profit margins and the explosive growth rates of companies such as: WeCo, Uber, B2B, Netflix and others, lead to overvaluation when the traditional valuation models are utilized.

Practical implementations: The study concludes by recommending alternative valuation models that utilize some of the specific findings of previous researchers on assessing terminal value, estimating cost of capital, and capital expenditures to address some of the peculiarities of the SDPs and adding to the rubrics and scorecards to account for nonfinancial factors such as switching costs, brand recognition and other intangibles. The inclusion of these would lead to an improved valuation of these types of companies and reduce the overall risk exposure of financial intermediaries that provide funding

Originality value: The audience for this type of research are: financial advisors, stock analysts and investors who appreciate the challenges that information asymmetry and uncertainty present in their efforts to correctly value stock and IPOs in this high-tech subsector.
\end{abstract}

Keywords: Valuation, weighted average cost of capital, financial ratios, financial intermediaries, supply-demand providers.

JEL codes: M40, M41.

Paper type: Research article.

${ }^{1}$ Ph.D., Prof., Department of Economics, Finance and Global Business, William Paterson

University of New Jersey, USA, tsanacasd@wpunj.edu;

*Paper presented at ICABE 2021 www.icabe.gr 


\section{Introduction}

Investments in high tech industries such as telecommunications, computer, computer software, social media and pharmaceuticals has been plagued with a high level of uncertainty associated with unpredictable high risk and the inability to estimate with accuracy the future outcomes or even the potential markets and market development. The reason is the limited amount of information of how the new technology would work in unproven fields. In addition, the limited generation of cash flows in the near future makes valuation less predictable and much riskier.

The advances in the information sector and the Internet have led to the growth of high tech companies in the supply and demand domain platform that offer consumers the ability to bypass the traditional means of accessing these services and engage in direct interaction. Examples include among others Uber, Weco, and Netflix.

These types of corporations have looked to financial institutions and investors for capital and they have embraced with major financial commitments even though the financial institutions have been unable to fully assess the risk of such investments, as well as, the value of the invested capital.

The traditional valuation and risk assessment models seem to be inferior, incompatible and inadequate in offering financial institutions and investors an accurate risk and valuation assessment due to radical changes in the financial, organizational and operational structure of firms as it pertains to access to financial markets.

The evidence from the markets indicates that, (a) the majority of high-tech companies would be acquired before they reach the stage of an IPO and (b) fundamental economic forces point to the next wave of mergers, acquisitions, downsizings, and liquidations as high-tech industries are under greater pressure to regroup. For example, in storage software and hardware, where technology is relatively mature and incentives for consolidation relatively high, companies choose to reap scale advantages by acquiring peers or to reposition by making acquisitions across industry segments. The presence of asymmetry in information renders the mergers/acquisitions difficult in at least two areas: valuation and risk assessment.

Traditionally startup companies have less access to capital markets to get debt financing due to increased risk and lack of company history (Herciu, 2017). These companies would usually rely almost entirely on private equity from angel investors and venture capitalists who would offer assistance in managing and advising the company leading to lower risk and positive returns when these become IPOs (Bamford and Douthett, 2013). 
High tech platform companies do not follow a similar pattern, and many of them, like WeCo and Uber have greater access to capital markets and are able to obtain significant debt financing before going public, which it could be argued increases their risk, particularly as there is significant information asymmetry between them and the financial institutions (Coleman et al., 2016).

In addition, the platform based companies pose issues in the accurate calculation of the WACC due to unorthodox financing strategies, in the negative cash flows, in the unclear paths to profitability, and in the unorthodox financing strategies and complex corporate structures. All of above-mentioned factors combined with the limited information make accurate valuation problematic and often lead to the overvaluation of innovative high growth firms.

It should be pointed out that government regulation has had an impact on the growth of high tech platform companies. To be more specific less regulation spurs innovation and growth which in turn drives self-regulation (Stefanadis, 2003) and reduces costs associated with information leakage to competition (Brown and Martinsson, 2019). The lack of oversight and regulation is dangerous for investors and other stakeholders (DuCharme et al., 2001)

Extensive government regulation on the other hand could affect the operations and the cash flows of these types of corporations. For example, in the UK Uber recently lost its license to operate in London (BBC News, 2019) one of its main revenue centers. Furthermore, both WeCo and Uber have recently had to fire thousands of employees to reduce working capital expenditure (Baca, 2019).

\section{Valuation}

There are numerous processes available to address the valuation issue: valuation of comparable public companies, evidence for comparable transactions and the discounted cash flow approach. Each of these does present unique challenges. The use of comparable public companies requires adjusting the performance for size, maturity, liquidity and performance.

The valuation based on financial tools as NPV and DCF has numerous advantages : generate financial estimates and income flows over time, estimate reasonably accurate cost and schedule, utilize historical data of past same projects, and consider expected risk in various projects stage.

The disadvantages are early project termination cannot be considered due to NPV and DCF approaches, yields poor outcomes in new product development portfolio, need similar project experience for evaluation. Additional limitations arise with respect to projected income as well as in the residual value of the initial investment. 


\section{Methodology}

The financial structure of various service provider platforms are analyzed and compared/contrasted with industry incumbents and examined regarding relevant research with respect to: capital structure, cost of capital, liquidity, enterprise structure and valuation methods. All of these are contextualized with regards to current and alternative valuation methods.

\subsection{Capital Structure}

Technology startups often have less access to debt financing compared to incumbents/peers due to their higher risk and because investors do not wish debt holders to supplant them as primary receivers of recouped funds should the business fail, however, businesses which are able to use corporate debt financing in their initial year of operation are "significantly more likely to survive and achieve higher levels of revenue three years after the firm's start-up" (Cole and Sokolyk, 2018). Table 1 shows comparisons between supply demand services (SDPs) and similar industry peers capital structure and their valuations showing increasing levels of leverage.

Table 1. Assets and Liabilities ( sources: Morningstar, Yahoo. NASDAQ, company pages)

\begin{tabular}{|l|l|l|l|l|l|}
\hline \$ millions & Assets & Liabilities & Equity & D/E & Market Cap \\
\hline Cabcharge 2018 & 139.58 & 28.98 & 110.60 & 0.26 & 128.887 \\
\hline A2B* & 190.66 & 59.344 & 131.322 & 0.47 & 156.12 \\
\hline Uber IPO 2019 & 23,988 & 17,196 & 6,792 & 2.53 & 50,305 \\
\hline Netlix IPO 2000 & 34,773 & 14,982 & 19,791 & 0.76 & 82,500 \\
\hline Netflix 2019 & $33,280.35$ & 26,393 & $7,582.15$ & 2.47 & 10,332 \\
\hline WeCoIPO 2019 & $8,644.91$ & $6,284.12$ & $2,360.75$ & 2.66 & 47,000 \\
\hline IWG IPO 2000 & 390.91 & 126.638 & 264,280 & 0.48 & 21,000 \\
\hline IWG 2019 & $4,461.34$ & $3,481.76$ & 979,587 & 3.55 & 3,647 \\
\hline AirBnB 2019 & $8,310.11$ & $5,886.30$ & -807.685 & -11.29 & 35,620 \\
\hline Amazon 2019 & 321,195 & 227,791 & 93,404 & 2.68 & $92,022,000$ \\
\hline E-Bay & 18,174 & 4,066 & 6,778 & 2.39 & $47,232,000$ \\
\hline
\end{tabular}

Source: Own study.

Interesting to note is the far higher valuation of WeCo compared to IWG when it has a similar D/E ratio, even compared to other SDPs at the point of IPO, like Uber and Netflix. An argument in support of this could be that larger firms use more debt in accordance with trade-off theory and that they have increased access to debt markets, this in turn "signals" to financial intermediaries that they are able to service this debt due to high performance and subsequently information is passed from debt to equity markets and share price rises (Coleman et al., 2016). 
It could, however, indicate that financial intermediaries are increasingly valuing growth potential in service delivery platforms which means they are allowing higher amounts of borrowing than would be expected from traditional companies within the same industry, resulting in the overvaluation of riskier firms

\subsection{Weighted Average Cost of Capital (WACC)}

For any business, there will be an optimal capital structure which is a mixture of debt and equity, this allows the business to take advantage of the tax shield afforded by debt, and reduce the WACC to its minimum point before the added costs of financial distress require an increased risk premium from investors (Modigliani and Miller, 1958). The WACC is used by many investors and financial institutions as the discount rate for discounted cash flow analysis when performing company valuations (Magni, 2015).

There is an issue however as WACC cannot be calculated accurately for private companies like WeCo which have not issued public equity, Uber does not have a Beta value that can be used to calculate its WACC and many service delivery providers like Netflix have negative cash flows.

For supply demand platforms ( SDPs), financial intermediaries must find alternate ways besides firm WACC in order to calculate firm value and indeed some research suggests WACC is not fully accurate due to its linear nature (Miller, 2009). This could contribute to an increase in non-traditional and less reliable forms of discounting/valuation resulting in overvaluation.

\subsection{Working Capital and Liquidity Management}

Table 2 shows that most of the service delivery platforms have better liquidity ratios than industry incumbents/peers, who could be due to their high margins or a requirement of financial institutions, investors and lenders that mandate a minimum capital reserve in order to reduce liquidity risk. In the case of $\mathrm{WeCo}$, their largest liability is, in fact, the long-term leases they have on their properties, which are recorded as expenses, a common method of off-balance-sheet financing. Should we include these as liabilities their liquidity ratios change dramatically.

Research has shown that bond markets price off-balance sheet financing in the same way as liabilities when valuing corporate bonds (Sengupta and Wang, 2011), however, in the case of WeCo this did not seem to be apparent until after their failed IPO. They then required a capital injection of $\sim \$ 10 \mathrm{~B}$ from SoftBank, their largest investor who gained control of the business, in order to remain solvent (Nussey, 2019). Working capital and liquidity in the form of private equity can help solve an issue for smaller firms and startups that lack access to affordable short-term financing due to their risk, and which in turn stifles growth (Beck and DemirgucKunt, 2006). 
Table 2. Liquidity Ratios

\begin{tabular}{|l|l|l|l|}
\hline millions & Current Assets & Current Liabilities & Current ratio \\
\hline Cabcharge* 2018 & 98.363 & 41.712 & 2.36 \\
A2B (2019) & 100.456 & 49.261 & 1.14 \\
\hline Uber IPO 2019 & 8,658 & 4,259 & 2.03 \\
\hline Netflix 2000 IPO & 21.240 & 10.212 & 2.08 \\
\hline Netflix 2019 & 6,179 & 6,856 & 0.73 \\
\hline WeCo IPO 2019 & 2,427 & 659.587 & 3.73 \\
& & With OBSF & With OBSF \\
& & $3,130.217$ & 0.79 \\
\hline IWG IPO 2000 & 299.777 & 317.883 & 0.94 \\
\hline IWG 2019 & 819 & $1,429.500$ & 0.57 \\
\hline E-Bay & 4,706 & 4,066 & 1.16 \\
\hline AirBnB & 6,561 & $5,233.760$ & 1.48 \\
\hline Amazon & 132,733 & 126,385 & 1.05 \\
\hline
\end{tabular}

Source: Morningstar, Yahoo Finance, NASDAQ, company web pages.

For entrepreneurs, securing backing from reputable private equity can also signal to large financial institutions creditworthiness and thus unlock increased short term financing opportunities (Cole and Sokolyk, 2018).

FMIs interpretation of future liquidity of service delivery platforms is still being debated. WeCo abandoned their IPO which in turn caused their high-yield bond prices to fall after investors suggested that their business model of taking out cheap long-term leases and then selling more expensive short term leases, would cause major liquidity problems should there be an economic downturn which reduced their occupancy rates (Sen, 2019).

Uber and Netflix have also been criticized by investors who argue that their revenue streams are not growing at a sufficient rate to sustain their growth which may cause liquidity problems, this has been used to explain the poor performance of Uber's share price since IPO (Wolverton, 2019).

\subsection{Enterprise Risk Structure and Management Strategy}

Many traditional firms which have greater access to capital markets engage in hedging strategies to manage their risk, with currency hedging being the most common form, usually through swaps, forwards, options and other derivative instruments (Morey and Simpson, 2001).

For smaller firms going through a growth phase, operational hedging is common whereby risk is managed through changes to operational structure rather than via financial instruments, such as the use of different money market accounts in different regions to balance cash inflows and outflows (Pantzalis et al., 2001). 
Figure 1. Organizational structure WeCo

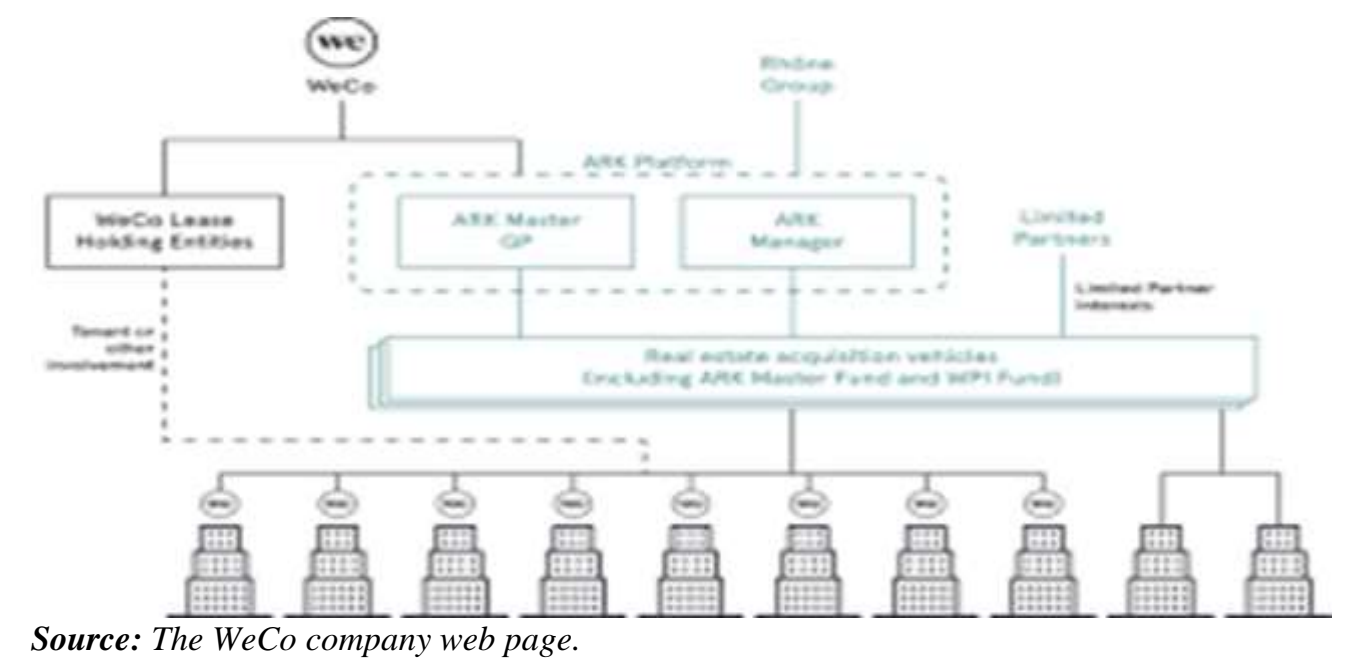

For many firms this is the extent of their risk management, however, in the case of some SDPs, they have unorthodox business structures and organizational charts to mitigate firm-specific risks. An example would be the risk of WeCo facing liquidity and solvency issues in case of an economic downturn, where they would still be liable for their long term leases but may see a decline in occupancy rates. In order to mitigate this risk, WeCo's company structure ( see figure above) and organizational chart has various parent companies and special purpose entities (SPEs), so that a failure of one, would not spread to the others.

These complex structures have been seen by investors before in some fraudulent companies were special purpose entities were used to hide losses and obfuscate financial data that financial intermediaries use among other things to correctly value a business (McLean and Elkind, 2004). The linkage of financial markets and the effects of contagion as shown through stock markets and global yield curve comovement (Byrne et al., 2019), also places questions on the effectiveness of this strategy.

The research has shown that in the context of FMIs and financing, the use of special purpose entities is associated with higher loan rates, collateral requirements and restrictive covenants due to the increase in information risk by lenders, as special purpose entities make it easier for firms to hide losses and manipulate earnings (Kim et al., 2017).

The same research found a strong link between the use of special purpose entities and restatement of financial data and more stringent non-price loan terms. It is surprising then that this did not seem to apply to WeCo in the way it may have for some of the other firms being examined such as Uber and Netflix. 


\subsection{Discounted Cash Flow (DCF)}

For private companies that are new technology providers, information asymmetry makes it difficult to calculate factors like WACC as there is not a suitable proxy for Beta and return on equity, as in the case of Uber and WeCo this leads to biased valuations (Elsner and Krumholz, 2013). WACC also assumes that the capital structure will remain constant which is an unrealistic assumption for SDPs.

Many of these firms have negative cash flow as they are loss-making and do not have clear paths to profitability like Uber. Others like Netflix are profitable but run on negative cash flows and are not planning on changing this model anytime soon. Calculating the terminal value of innovative, early-stage service delivery platforms (SDPs) is also more difficult and subjective (Holland, 2018) as is valuing intangible assets which many SDPs attribute a lot of value (Matsuura, 2004)

\subsection{Multiples Valuation}

Selecting the correct multiples such as Price to Earnings or Enterprise value to EBITDA are not suitable for service provider platforms which are not yet public, are new and growing with unstable financial structures, or have negative earnings such as WeCo, Uber and Netflix. Even if suitable multiples can be found, the unique nature of industry-disrupting service delivery platforms (SDPs) could mean comparison to "similar" enterprises is impossible or not suitable.

Research has shown that valuations based on multiples were one of the contributing factors to the dot com bubble of the '90s and a switch to a more comprehensive DCF based approach has been taken by many financial intermediaries (Glaum and Friedrich, 2006), however, we have seen this is unsuitable for many service delivery platforms.

\subsection{Alternative Valuation Methods}

There is a growing research base regarding valuation techniques for HGTCs which promise to solve some of the issues discussed for SDPs. Doffou, (2015) built on the model created by Schwartz and Moon, (2001) for valuing internet companies that are not "steady-state". By including stochastic costs, future financing probability, capital expenditures for growth and taking depreciation into account, a more accurate valuation model was created and tested on firms like eBay, Facebook and Amazon.

The model could be further improved by incorporating the work of Miller, (2018) who formed a more accurate way of calculating the terminal value of HGTCs. This approach may be appropriate for SDPs that may arguably outperform the market for longer than average, due to innovation protected by intellectual property laws. 
Further improvements to the proposed model would be achieved through the work of Elsner and Krumholz, (2013), on valuation using an imprecise cost of capital, to create a sensitivity analysis giving an estimated valuation range to be used by financial firms to judge the reliability of the results

\section{Conclusion}

The institutions which affect the operation of service delivery providers(SDPs) have not kept pace with their rate of change and innovation. The social norms and legal rules which govern FMIs and SDPs need to be updated to make them more transparent as they grow, as do tools for valuing firms to reduce the risk of biased overvaluation as this often results in real risk to investors through the loss of funds and stakeholders like employees through the loss of jobs as evidenced by WeCo and Uber.

Alternate valuation models and how they could be combined have been proposed in this paper that take into account stochastic costs, future financing probability, capital expenditures and depreciation. This is combined with a more reliable way of calculating their terminal value and is enhanced with a sensitivity analysis tool for firms with an imprecise cost of capital which may be able to more accurately value SDPs based on their non-traditional financial and operational structures, their increasing access to FMIs, and accelerated growth compared to industry incumbents/peers.

A Rubrics and ScoreCard evaluation method could be developed which can be used by FMIs in conjunction with these alternative valuation methods to sanity check results and decide qualitatively if valuations are justified by non-financial factors like brand recognition and consumer switching costs when financials are not traditionally strong compared to industry incumbents/peers.

\section{Recommendations}

A new alternative valuation method for SDPs based on a combination of the contemporary research and a qualitative Rubrics and Scorecard evaluation method is proposed. The combination recommended and proposed above would produce more accurate valuations of SDPs as well as giving FMIs a simple tool to valuations against industry incumbents/peers to qualitatively assess whether FMIs are fairly valuing SDPs and reduce risks associated with overvaluation

\section{References:}

Archer, N., Ghasemzadeh, F. 1999. An integrated framework for project portfolio selection. International Journal of Project Management, 17(4), 207-216.

Brennan, M.J., E.S Schwartz, S.E. 1985. Evaluating Natural Resources Investment. Journal of Business, 58, 135-157. 
Baca, M.C. 2019. WeWork planning to cut thousands of jobs. Washington Post. https://www.washingtonpost.com/technology/2019/11/18/wework-planning-cutthousands-jobs/

Bamford, C.E., Douthett, E.B. 2013. Venture Capital and Risk Management: Evidence from Initial Public Offerings. Journal of Managerial Issues, 25, 220.

BBC News. 2019. Uber loses licence to operate in London (WWW Document). BBC News. https://www.bbc.com/news/business-50544283.

Beck, T., Demirguc-Kunt, A. 2006. Small and medium-size enterprises: Access to finance as a growth constraint. Journal of Banking \& Finance, 30, 2931-2943.

Byrne, J.P., Cao, S., Korobilis, D. 2019. Decomposing global yield curve co-movement. Journal of Banking \& Finance, 106, 500-513.

Carlsson, C., Fuller, R., Heikkila, M., Majlender, P. 2007. A fuzzy approach to R\&D project portfolio selection. International Journal of Approximate Reasoning, 44, 93-105.

Chien, C. 2002. A portfolio-evaluation framework for selecting R\&D projects. R\&D Management, 32(4), 359-368.

Childs, P.D., A.J Triantis, J.A. 1999. Dynamic R\&D Investment Policies. Management Policies, 45(10), 1359-1377.

Cottrell, T., Sick, G. 2001. First Mover (Dis-) Advantage and Real Options. University of Calgary Faculty of Management Finance Area.

Cohen, W., Levinthal, D. 1990. Absorptive capacity: a new perspective on learning and innovation. Administrative Science Quarterly, 35(1), 128-152.

Chi, J.D., Su, X. 2017. The Dynamics of Performance Volatility and Firm Valuation. Journal of Financial \& Quantitative Analysis, 52, 111-142.

Cole, R.A., Sokolyk, T. 2018. Debt financing, survival, and growth of start-up firms. Journal of Corporate Finance 50, 609-625.

Coleman, S., Cotei, C., Farhat, J. 2016. The debt-equity financing decisions of U.S. startup firms. Journal of Economics and Finance, 40, 105.

Day, G. 2007. Is it real? Can we win? Is it worth doing? Managing risk and reward in an innovation portfolio. Harvard Business Review, 85(12), 110-120.

Dixit, A.K., Pindyck, S.R. 1994. Investment under Uncertainty. Princeton NJ, Princeton University Press.

Doffou, A. 2015. An Improved Valuation Model for Technology Companies. International Journal of Financial Studies 3, 162-176.

DuCharme, L.L., Malatesta, P.H., Sefcik, S.E. 2001. Earnings Management: IPO Valuation and Subsequent Performance. Journal of Accounting, Auditing \& Finance 16, 369396.

Ednlister, R.O. 1972. An Empirical Test of Financial Ratio Analysis for Small Business Failure Prediction. Journal of Financial \& Quantitative Analysis 7, 1477-1493.

Elsner, S., Krumholz, H.C. 2013. Corporate Valuation Using Imprecise Cost of Capital. Journal of Business Economics 83, 985-1014.

Glaum, M., Friedrich, N. 2006. After the "Bubble": Valuation of Telecommunications Companies by Financial Analysts. Journal of International Financial Management \& Accounting 17, 160-174.

Hashim, N.A., Strong, N.C. 2018. Do Analysts' Cash Flow Forecasts Improve Their Target Price Accuracy? Contemporary Accounting Research, 35, 1816-1842.

Herciu, M. 2017. Financing Small Businesses: From Venture Capital to Crowdfunding. Studies in Business \& Economics 12, 63-69.

Holland, D.A. 2018. An Improved Method for Valuing Mature Companies and Estimating Terminal Value. Journal of Applied Corporate Finance, 70. 
Healy, M.P., Palepu, K. 2001. Information asymmetry, corporate disclosure and the capital markets: A review of the empirical disclosure literature. Journal of Accounting and Economics, 31(1-3), 405-440.

Henriksen, A.D., Traynor, A.J. 1999. A practical R\&D project-selection scoring tool. IEEE transactions on engineering management, 46(2), 158-170.

Inselbag, I., Kaufold, H. 1997. Two DCF Approaches for Valuing Companies Under Alternative Financing Strategies (and How to Choose Between Them). Journal of Applied Corporate Finance, 10, 114.

Jovanovic, B. 2019. The entrepreneurship premium. Small Bus Econ, 53, 555-568.

Kim, J.B., Song, B.Y., Wang, Z. 2017. Special purpose entities and bank loan contracting. Journal of Banking \& Finance, 74, 133-152.

Kim, Y.J., Sanders, G.L. 2002. Strategic actions in information technology investment based on real option theory. Decision Support Systems, 33(1), 1-11.

Lambrecht, B., Perraudin, W. 2003. Real Options and Preemption under Incomplete Information. Journal of Economic Dynamics and Control, 27, 619-643.

Lensink, R., Sterken, E. 2001. Asymmetric Information option to wait to invest and the optimal level of investment. Journal of Public Economics, 79(2), 365-374.

Lofgren, K.G, Persson, T., Weibull, W.J. 2002. Markets with Asymmetric Information: The Contributions of George Akerlof, Michael Spence and Joseph Stiglitz. Scandinavian Journal of Economics, 104(2), 195-211.

Magni, C.A. 2015. Investment, financing and the role of ROA and WACC in value creation. European Journal of Operational Research, 244, 855-866.

Matsuura, J.H. 2004. An Overview of Intellectual Property and Intangible Asset Valuation Models. Research Management Review, 14, 33-42.

McLean, B., Elkind, P. 2004. The Smartest Guys in the Room: The Amazing Rise and Scandalous Fall of Enron. Penguin, London.

Miller, R.A. 2009. The weighted average cost of capital is not quite right. The Quarterly Review of Economics and Finance, 49, 128-138.

Miller, T.W. 2018. Terminal values for firms with growth opportunities: explaining valuation and IPO price behavior. Studies in Economics \& Finance, 35, 244-272.

Modigliani, F., Miller, M.H. 1958. The Cost of Capital, Corporation Finance and the Theory of Investment. The American Economic Review, 48, 261-297.

Pantzalis, C., Simkins, B.J., Laux, P.A. 2001. Operational Hedges and the Foreign Exchange Exposure of U.S.Multinational Corporations. Journal of International Business Studies, 32, 793-812.

Rothman, J. 2009. Manage your project portfolio: increase your capacity and finish more projects. Raleigh, NC, The Pragmatic Bookshelf.

Sharpe, P., Keelin, T. 1998. How SmithKline Beecham makes better resource-allocation decisions. Harvard Business Review, 76(2), 45-57.

Smit, H.T.J., Ankum, A.L. 1993. A Real Options and Game-Theoretic Approach to Corporate Investment Strategy Under Competition. Financial Management, 22, 241250.

Schwartz, E.S., Moon, M. 2001. Rational pricing of internet companies revisited. Financial Review, 36, 7-26.

Sengupta, P., Wang, Z. 2011. Pricing of off-balance sheet debt: How do bond market participants use the footnote disclosures on operating leases and postretirement benefit plans? Accounting and Finance, 51, 787-808.

Trigeorgis, T. 1996. Real Options Managerial Flexibility and Strategy in Resources Allocation. Cambridge, MA, MIT Press. 
Wolverton, T. 2019. Sure, Uber didn't leave any money on the table, but its IPO was nothing to celebrate and it could haunt the company and its execs for years to come.

Business Insider. https://www.businessinsider.com/why-uber-disappointing-ipocould-haunt-company-for-years-2019-5. 